\title{
Employee Stock Options And Diluted Earnings Per Share
}

David T. Doran, (Email: dtd1@psu.edu), Penn State - Erie

\begin{abstract}
At the time of this writing, SFAS No.123 (1995) prescribes GAAP in accounting for employee stock options. It allows firms to choose either the intrinsic or fair value method in determining the amount of compensation expense recognized for employee stock options. The choice of method affects the numerator of the earnings per share (EPS) calculation. The FASB recently issued a revised SFAS No. 123 (2004) which will require uniform application of the fair value method. GAAP also requires that the denominator for the diluted EPS calculation be increased for incremental shares under the treasury stock method. SFAS 128 requires the treasury stock method be applied where the proceeds from the assumed exercise of options are used to acquire shares of the firm's outstanding stock at the average market price for the period. Previous to SFAS No. 128, $A P B$ Opinion No. 15 required that the higher of average or period ending stock price be used in determining the number of shares reacquired with the proceeds from the assumed exercise of stock options. This paper develops a simple one period model that assumes a risk free environment with complete certainty conditions in testing the accuracy of EPS calculated under GAAP using the fair value method vs. the intrinsic value method.
\end{abstract}

The results indicate that EPS reported under the intrinsic value method are overstated, and further indicate that a combination of both the fair value method and the treasury stock method is needed in calculating diluted EPS. This fair value and treasury stock method combination is shown to not "double count" the stock option's impact upon EPS. The results also indicate a slight misstatement of diluted EPS under the fair value method when applying the treasury stock method requirements of SFAS No. 128. Correct EPS results when shares are assumed reacquired for the treasury at the higher year ending price, consistent with superseded APB 15. However, the diluted EPS misstatement is so slight that the FASB's rationale for always requiring the use of average period price seems likely to be justified. The findings of this research support the requirements of SFAS No. 123 (revised 2004) and SFAS No. 128.

\section{BACKGROUND}

$T$

here has been significant controversy surrounding the appropriate accounting by employers for employee stock options. Accounting Principles Board Opinion No. 25 (APB 25) required employers to only recognize the intrinsic value of stock options as expense in the income statement. The intrinsic value was determined at the "measurement" date (usually the date of grant) as the amount of fair value of the optioned shares in excess of their option priced amount. If the firm sets the option price amount at least equal to the market price on the grant date, there is no resulting intrinsic value and no compensation expense is recognized. The FASB contends that this is generally the case in practice: "Most fixed stock option plans - the most common type of stock option plan - have no intrinsic value at the grant date, and under Opinion 25 no compensation expense is recognized for them." 1

Significant debate preceded the FASB's original issuance of Statement No. 123 in 1995. The FASB indicated its strong support for estimating the fair value of employee stock options and requiring its recognition as

\footnotetext{
${ }^{1}$ Statement of Financial Accounting Standards No. 123 (October 1995), Summary.
} 
expense in the income statement (the fair value method). Among the arguments (there are many) put forth by expensing opponents was the supposed "double counting" of the stock option's impact when determining earnings per share (EPS). The FASB indicated: "Some respondents that opposed recognizing compensation cost for employee stock options said that to do so would "double count" the effect of issuing stock options. The dilutive effect of any inthe-money stock options is included in the denominator of earnings per share, and a reduction in net income (the numerator) would, in their view, create an inappropriate dual effect." ${ }^{2}$ Under significant political pressure, the FASB originally encouraged, but did not require the fair value method be used in accounting for employee stock options. Under SFAS No. 123 (1995) firms were able to continue using the intrinsic value method for purposes of financial statement recognition of compensation expense.

The FASB has recently issued a revised Statement No. 123 (December 2004) that requires the fair value method to be used in accounting for stock options granted during reporting periods that begin after June $15,2005 .^{3}$ Accordingly, those firms that issue employee stock options after the scheduled effective date will no longer be permitted to account for them under the intrinsic value method.

In the case of outstanding stock options, diluted earnings per share must include incremental shares determined under the treasury stock method. This method assumes all options are exercised at the beginning of the period (or date of grant if issued during the period). The proceeds from this assumed issuance are used to purchase shares of the firm's stock for the treasury. If the option price is less than the reacquisition price, more shares will be assumed issued than are assumed purchased for the treasury. This difference represents "incremental shares" that are added to the denominator of the EPS calculation with a resulting dilution. Prior to the issuance of SFAS No. 128, the number of incremental shares was determined under APB No. 15. SFAS No. 128 states: "The Board made one change to the treasury stock method prescribed in Opinion 15. This Statement requires that the average stock price for the period always be used in determining the number of treasury shares assumed purchased with the proceeds from the exercise of options or warrants rather than the higher of the average or ending stock price as prescribed by Opinion 15. The Board believes that use of the average stock price is consistent with the objective of diluted EPS to measure earnings per share for the period based on period information and that use of end-of-period data or estimates of the future is inconsistent with that objective. If purchases of treasury shares actually were to occur, the shares would be purchased at various prices, not at the price at the end of the period. In addition, use of an average stock price eliminates the concern that end-of-period fluctuations in stock prices could have an undue effect on diluted EPS if an end-of-period stock price were required to be used. Respondents generally agreed with the requirement to use average stock price."

\section{PURPOSE OF STUDY AND METHODOLOGY}

This study tests the "double counting" notion. That notion contends that by requiring firms to both recognize the fair value of employee stock options as expense in the income statement under the fair value method and to assume incremental shares are issued under the treasury stock method results in EPS understatement since "earnings per share would be hit twice". That is, requiring the numerator to be decreased by the fair value of employee compensation expense and also requiring that the denominator be increased for incremental shares, unfairly reduces EPS twice.

This study also examines the reasonableness of SFAS No. 128 requirement that the average market price of the firm's stock always be used in determining incremental shares under the treasury stock method. A significant observed misstatement of EPS would indicate that the average market price should not be mandated for use in all circumstances.

\footnotetext{
${ }^{2}$ Ibid, Paragraph 100 .

${ }^{3}$ Small business issuers and nonpublic entities must comply six months later. Statement of Financial Accounting Standards No. 123 (Revised 2004), Paragraph 69.

${ }^{4}$ Statement of Financial Accounting Standards No. 128 (February 1997) Paragraph 107.

${ }^{5}$ Statement of Financial Accounting Standards No. 123, Revised (December 2004) Paragraph B27.
} 
A simple one period model that assumes complete certainty is developed. The fair value of employee compensation is given, and the complete certainty assumption indicates that the employee and the firm should be economically indifferent to various compensation schemes (cash transfer, stock transfer, or stock option grant). Given this economic equivalence, the true amount of EPS is "known" and should be consistent regardless of the compensation scheme assumed. Initially EPS is calculated under the cash and stock transfer scenarios. For both of these immediate transfer scenarios, calculated EPS amounts are found to equal the "known" EPS. This indicates that GAAP is appropriate in accounting for a cash transfer or a stock transfer. Diluted EPS is then calculated assuming the stock option scenario. The fair value and the intrinsic value methods are applied in conjunction with the treasury stock requirements of SFAS No. 128. If there is in fact a "double counting" effect, EPS observed in the case of the fair value method should be understated, while EPS observed in the case of the intrinsic value method should equal the "known" (correct) amount.

\section{MODEL}

The analysis is based upon various compensation schemes by a firm for an employee who renders services to the firm worth $\$ 1$ million at 1/1/1. This simple one period model includes the following assumptions:

1. There is no risk, and all entities earn an available $10 \%$ risk free rate of return.

2. There are no dividends, taxes, or transaction costs.

3. The book value of the firm is $\$ 220$ million at $1 / 1 / 1$.

4. The firm has 10 million shares of stock outstanding at $1 / 1 / 1$ and the market value per share is $\$ 22$, the total market value of the firm is $\$ 220$ million.

5. If a stock option is used as compensation, it vests immediately and is fully transferable.

a. Under the assumptions of the model, all participants are certain that the market value of the stock in one year (1/1/02) will be $\$ 24.20$ per share. With that being the case, the employee and the firm should be indifferent between compensation packages of:

b. $\quad$ Compensation of $\$ 1$ million cash paid on $1 / 1 / 1$,

c. Transferring 45,454.54.... shares of stock on 1/1/1 (@ $\$ 22 / \mathrm{sh}=\$ 1,000,000)$, or

d. Granting the employee an option to purchase however many shares of the firm's stock on 1/1/02, where: $(\$ 24.20-$ option price $) \times$ requisite \# of shares $=\$ 1.1$ million $(\$ 1$ million @ $110 \%)$.

The FASB indicates that firms generally set the option price at least at the stock's market value on the grant date, and in doing so avoid creating any intrinsic value. This minimum option price would result in granting an option to buy 500k shares in one year at $\$ 22$ per share. This option (500k shares at $\$ 22)$ is examined along with options to purchase: 220k shares @ \$19.20,110k shares at $\$ 14.20$, and $45,454.54 \ldots$ shares at $\$ 0$ ).

Given the economic equivalence of the cash transfer vs. stock transfer vs. stock option compensation scenarios, the computed earnings per share should be consistent across these alternatives.

\section{RESULTS}

Table one provides the GAAP based calculation of EPS in the case of cash compensation at 1/1/01 (Panel A) and stock transfer at 1/1/01 (Panel B). They both provide the true "known" amounts of earnings per share. The year ended 12/31/01 EPS is calculated at $\$ 2.20$ for both scenarios. This is the correct performance measure given the model assumptions of a requisite $10 \%$ return and the 1/1/01 fair value of the stock of $\$ 22$ per share. Note that the income before compensation expense and net income are $\$ 100,000$ higher in the case of the stock transfer scenario. This is attributed to the additional cash ( $\$ 1$ million) being retained by the firm at 1/1/01 and invested to earn the risk free rate of $10 \%$. Note also that this numerator increase is offset by a proportionate denominator increase $(45,454.54 \ldots$ additional shares) such that the "known" amount of EPS results. In the case of stock compensation, the appropriate numerator is $\$ 22.1$ million of net income, while the appropriate denominator is $10,045,454.54 \ldots$ shares. 
Table 1: Employee Receives Cash or Stock on 1/1/01

\begin{tabular}{|c|c|}
\hline \multicolumn{2}{|l|}{ Panel A: Cash Transfer } \\
\hline \multicolumn{2}{|c|}{$\begin{array}{l}\text { Under the cash compensation at 1/1/01 scenario, the true (and GAAP) earning of the firm is } \\
\text { calculated as follows (w/ } 10 \% \text { return): }\end{array}$} \\
\hline Income before compensation & \$23 million \\
\hline Compensation expense & $\$ 1$ million \\
\hline Net income & $\$ 22$ million (to equal $10 \% \mathrm{rtn}$ ) \\
\hline Number of shares & 10 million \\
\hline Earnings per share & $\$ 2.20$ \\
\hline \multicolumn{2}{|l|}{ Panel B: Stock Transfer } \\
\hline \multicolumn{2}{|c|}{$\begin{array}{l}\text { Under the } 45,454.54 \ldots \text { shares transferred at } 1 / 1 / 01 \text { for } \$ 0 \text { scenario, the true (and GAAP) earnings of } \\
\text { the firm is still } 2.20 \text { per share. It is calculated as: }\end{array}$} \\
\hline Income before compensation & $\$ 23.1$ million $(23 \mathrm{~m}+.1 \mathrm{~m})$ \\
\hline Compensation expense & 1.0 million \\
\hline Net income & \$22.1 million \\
\hline Number of shares & $10.04545 \ldots$ million $(10 \mathrm{~m}+.04545 . . \mathrm{m})$ \\
\hline Earnings per share & $\$ 2.20$ \\
\hline
\end{tabular}

Table 2: Diluted EPS assuming Stock Option Compensation Incremental Treasury Shares Purchased at Average Period Price

\begin{tabular}{|c|c|c|c|c|}
\hline \multicolumn{5}{|c|}{ Panel A: Intrinsic Value Method } \\
\hline & 500k @ \$22 & 220k@ \$19.20 & 110k @ \$14.20 & $45.45 . . \mathrm{k} @ \$ 0$ \\
\hline Comp. Exp. & $\$ 0$ & $\$ 616 \mathrm{k}$ & $\$ 858 \mathrm{k}$ & $\$ 1$ million \\
\hline Net Income & $\$ 23.1 \mathrm{mil}$ & $\$ 22.484 \mathrm{mil}$ & $\$ 22.242 \mathrm{mil}$ & $\$ 22.1 \mathrm{mil}$ \\
\hline Incremental Shs. & 23,810 & 37,143 & 43,381 & 45,455 \\
\hline Total Shares & $10.02381 \mathrm{mil}$ & $10.037143 \mathrm{mil}$ & $10.042381 \mathrm{mil}$ & $10.045455 \mathrm{mil}$ \\
\hline EPS & $\$ 2.305$ & $\$ 2.24$ & $\$ 2.215$ & $\$ 2.20$ \\
\hline \multicolumn{5}{|c|}{ Panel B: Fair Value Method } \\
\hline & 500k@ @22 & 220k@\$19.20 & 110k@\$14.20 & 45.45.. k@\$0 \\
\hline Comp. Exp. & $\$ 1$ million & $\$ 1$ million & $\$ 1$ million & $\$ 1$ million \\
\hline Net Income & $\$ 22.1 \mathrm{mil}$ & $\$ 22.1 \mathrm{mil}$ & $\$ 22.1 \mathrm{mil}$ & $\$ 22.1 \mathrm{mil}$ \\
\hline Incremental Shs. & 23,810 & 37,143 & 42,381 & 45,455 \\
\hline Total Shares & $10.042381 \mathrm{mil}$ & $10.037143 \mathrm{mil}$ & $10.042381 \mathrm{mil}$ & $10.045455 \mathrm{mil}$ \\
\hline EPS & $\$ 2.205$ & $\$ 2.202$ & $\$ 2.201$ & $\$ 2.20$ \\
\hline
\end{tabular}

Table 2 illustrates diluted EPS under the intrinsic value method (Panel A) and the fair value method (Panel B). Consistent with SFAS No. 128 the number of incremental treasury shares is determined using the average for the year market value of the stock. The average market value used is the arithmetic average of the beginning and ending values per share (\$22 and \$24.20, respectively), which equals $\$ 23.10$ per share.

As can be seen from Table 2 Panel A, calculated EPS is generally overstated under the intrinsic value method. The amount of the overstatement is most pronounced when there is no intrinsic value compensation expense recognition (500k shares@\$22 per share). Recall that the FASB indicates that most stock option grants set the minimum option price at the grant date market value so that no intrinsic value results. Under this "most typical" case, EPS is observed to be overstated by about $4.7 \%$ relative to the "known" amount (\$2.305 vs. \$2.20). The EPS overstatement is eliminated as the option price decreases and the corresponding intrinsic value amount of compensation expense (numerator) approaches fair value ( $\$ 1$ million). Note also that as the option price decreases, the incremental shares under the treasury stock method increase toward $45,454.54 \ldots$ shares, the same number of 
shares observed in the case of the stock transfer scenario. Only when the option price is set at $\$ 0$ is the "known" EPS observed under the intrinsic value method.

Table 2 Panel B indicates a general overstatement of EPS when the fair value method is applied, but the observed amounts are much closer to the "known" amount. Consistent with the intrinsic value method, the overstatement is largest when the employee is granted the option to purchase 500k shares at $\$ 22$ per share. However, this overstatement is only .23\% relative to the "known" amount ( $\$ 2.205$ vs. $\$ 2.20)$. By recognizing the fair value of the option as compensation expense, net income (the numerator) is always the same as that for the "known" amount under the stock compensation scenario. The slight overstatement of EPS is solely attributable to the understatement of incremental shares (the denominator) under the treasury stock method. Only in the case of $45,454.54 \ldots$ shares at $\$ 0$ does the denominator reach the number of shares observed under stock transfer scenario.

Table 3: Diluted EPS assuming Stock Option Compensation Fair Value Method with Incremental Treasury Shares Purchased at Period Ending Price

\begin{tabular}{|l|l|l|l|l|}
\hline & $500 \mathrm{k} @ \$ 22$ & $220 \mathrm{k} @ \$ 19.20$ & $110 \mathrm{k} @ \$ 14.20$ & $45.45 . . \mathrm{k} @ \$ 0$ \\
\hline Comp. Exp. & $\$ 1 \mathrm{million}$ & $\$ 1 \mathrm{million}$ & $\$ 1 \mathrm{million}$ & $\$ 1 \mathrm{million}$ \\
\hline Net Income & $\$ 22.1 \mathrm{mil}$ & $\$ 22.1 \mathrm{mil}$ & $\$ 22.1 \mathrm{mil}$ & $\$ 22.1 \mathrm{mil}$ \\
\hline Incremental Shs. & 45,455 & 45,455 & 45,455 & 45,455 \\
\hline Total Shares & $10.045455 \mathrm{mil}$ & $10.045455 \mathrm{mil}$ & $10.045455 \mathrm{mil}$ & $10.045455 \mathrm{mil}$ \\
\hline EPS & $\$ 2.20$ & $\$ 2.20$ & $\$ 2.20$ & $\$ 2.20$ \\
\hline
\end{tabular}

Table 3 illustrates the fair value method applied in conjunction with the superseded treasury stock requirements prescribed under APB Opinion No. 15. Under APB 15, shares were assumed purchased for the treasury at the higher of average or year ending stock price. Since the model used here assumes no dividends and a risk free rate of return, the year ending price of the stock will always be higher than its average price for the period. As illustrated in Table 3, if we apply the fair value method while assuming the treasury shares are purchased at the year ending price (\$24.20), EPS is consistently observed to equal the "known" amount. This occurs because the denominator is consistently equal to the number of shares outstanding under the stock transfer compensation scenario.

\section{CONCLUSIONS}

The results in Table 2 indicate that there is no "double counting" effect on EPS when stock options are accounted for by both applying the fair value method in recognizing compensation expense (decreasing the numerator) and also increasing the denominator for incremental shares assumed issued under the treasury stock method. Application of the intrinsic value method results in relatively large overstatements of earnings per share, when compared to the relatively small misstatements when the fair value method is applied. The analysis demonstrates that a reduction in the numerator (which generally only occurs under the fair value method), and an increase in the denominator for incremental shares assumed issued under the treasury stock method are both necessary in providing a true measure of diluted EPS. These results provide support for the FASB's issuance of SFAS No. 123 (revised 2004), since it will no longer allow firms to account for employee stock options under the intrinsic value method, but instead will require uniform application of the fair value method. This should provide more comparable, relevant, and representationally faithful EPS information to users.

The results in Table 3 indicate that EPS may sometimes be more accurately presented by using the period ending stock price for purposes of determining the number of shares purchased for the treasury under the treasury stock method. However the FASB's rationale for requiring use of the average for the period stock price (i.e., likelihood of the firm to purchase shares throughout the period, and the potential for EPS distortions caused by end-of- 
period fluctuations in the stock price) seem justified given the small EPS misstatements observed here. ${ }^{6}$ The model applied in this study assumes complete certainty and no dividends. These assumptions negate the possibility of fluctuations in the stock price at the period's end. Given the implications of the model's assumptions and the small amounts of observed EPS misstatements, it is concluded that the relative benefit of always using the average market price under the treasury stock method likely exceeds the relatively small cost associated with potential EPS misstatement. The results support the requirement of SFAS No. 128 that the average stock price for the period should always be used in determining the number of shares assumed purchased for the treasury under the treasury stock method.

\section{FUTURE RESEARCH}

This study employed a simple one period model that assumed complete certainty, no dividends, no taxes, and no transaction costs. Future research can expand upon the contributions made here by examining EPS in the case of employee stock options while employing a multi-period model and relaxes one or more of the simplifying assumptions.

\section{REFERENCES}

1. Accounting Principles Board, Opinion No. 15, Earnings per Share, May 1969.

2. Accounting Principles Board, Opinion No. 25, Accounting for Stock Issued to Employees, October 1972.

3. Financial Accounting Standards Board, Statement of Financial Accounting Standards No. 123, Accounting for Share-Based Compensation, October 1995.

4. Financial Accounting Standards Board, Statement of Financial Accounting Standards No. 128, Earnings per Share, February 1997.

5. Financial Accounting Standards Board, Statement of Financial Accounting Standards No. 123 (revised 2004), Share-Based Payment, December 2004.

\footnotetext{
${ }^{6}$ Although no longer authoritative, APB No. 15 identified 3\% as the materiality threshold for earnings overstatement by then mandating the presentation of "fully diluted" EPS in addition to the presentation of "primary" EPS. The .23\% misstatement observed here is less than one tenth of that previously prescribed materiality threshold.
} 